\author{
Milan Gojak \\ Associate Professor \\ University of Belgrade \\ Faculty of Mechanical Engineering \\ Filip Ljubinac \\ Mechanical design engineer \\ Pollino Cold Storage System \\ Belgrade \\ Miloš Banjac \\ Full Professor \\ University of Belgrade \\ Faculty of Mechanical Engineering
}

\section{Simulation of Solar Water Heating System}

The paper presents a mathematical model of the solar water heating system. The analyzed solar system consists of flat collectors, two water storage tanks, outer heat-exchanger and a source of auxiliary energy. The implemented model enables simulation of system operation and determination of appropriate energy characteristics of the system and its elements for different locations (climatic data), orientations of collectors, thermal characteristics of system components, as well as different dynamics of hot water consumption. Results of the simulation are presented for the days of a typical meteorological year for Belgrade and the daily profile of hot water consumption. The analysis of the energy performances of the system is presented. The results obtained by simulation were compared with the results obtained with the f-chart method of calculation.

Keywords: Solar Energy; Water Heating; Mathematical model; Simulation

\section{INTRODUCTION}

The usage of energy from fossil fuels has many negative effects on the environment, which has been talked about in recent years in the professional community and in the general public. Therefore, there is a recommendation, as well as an obligation, to increase the contribution of energy usage from renewable and ecologically clean sources. In that sense, the usage of solar energy has a number of advantages. From different uses, water heating is one of the most favorable ways to use solar energy (it uses at a location where there is a need, the efficiency is higher than in other cases, the system is simple). For these reasons, solar water heating is widespread throughout the world. Solar systems for hot water production should be optimally designed and operated. The proper sizing of the components of a solar system is a complex problem which includes predictable (collector and other components performance characteristics) and unpredictable (weather data) components. One of the most important data for the application of technologies that use solar energy is properly determination of soler energy potential [1]. Computer modeling of thermal systems has many advantages (eliminate the expense prototypes, provide through understanding of system operation and component interactions, possibility to optimize the system components, etc) [2].

In the literature there are many examples of modeling of solar water heating systems for adopted assumptions and specific working conditions. A review and latest developments and advancement of water heating system for solar energy applications is presented in the paper [3]. Simulations of a performance of a

Received: July 2018, Accepted: September 2018

Correspondence to: Dr Milan Gojak

Faculty of Mechanical Engineering,

Kraljice Marije 16, 11120 Belgrade 35, Serbia

E-mail:mgojak@mas.bg.ac.rs

doi: $10.5937 /$ fmet1901001G

(C) Faculty of Mechanical Engineering, Belgrade. All rights reserved simple solar system with a dynamic model for storage tank only, while for other components of a static model applied are shown in articles [4,5]. Article [6] shows sensitivity analysis of solar system elements through dynamic simulation, while article [7] describes the general models of solar system components and models of thermosyphon and drain-back solar systems for preparation of domestic hot water. Paper [8] presents the procedure and the software for sizing small solar water heating systems where input data are based on monthly averaged values. A solar system for the domestic hot water production is analyzed in article [9] by means of a dynamic approach based on a Matlab/Simulink model. The $f$-chart method was developed as simplified design tool which provides excellent matching with the results obtained by detailed simulations [10]. Method gives $f$, the fraction of the monthly load supplied by solar energy.

This paper presents the mathematical model and the results of simulation of the operation of the solar system for heating sanitary water for the location of Belgrade, Serbia. For each component of the system the model is fully dynamic. It takes into account the daily and annual variations of the temperature of the outside air and solar radiation, as well as variations in load - in the consumption of hot water. The developed software enables analysis of the system operation and determination of energy indicators of its operation. The results obtained by numerical simulation were compared with results obtained by using the $f$-chart method of calculation.

\section{DESCRIPTION OF THE SOLAR SYSTEM}

The scheme of the analyzed solar system is shown in Figure 1. The system is predicted to provide hot water for the hotel. The system consists of a field with 50 flat collectors, which are connected - five collectors in a series with ten parallel rows. The collectors are set up with a slope of $45^{\circ}$ and oriented to the south. The 
system has two hot water storage tanks, each of $5 \mathrm{~m}^{3}$ volume, which are located inside the building. The working fluid in the collector's circuit is the mixture of propylene glycol $(40 \%)$ and water $(60 \%)$. In the heat exchanger, fluid from the collectors transfers energy to the water coming from the storage tank. The heat exchanger is located outside the storage tank. The cold water supply enters the storage tank S1 at the bottom, the heated water exits from the top and then flows into the storage S2. From the top of the storage tank S2, the

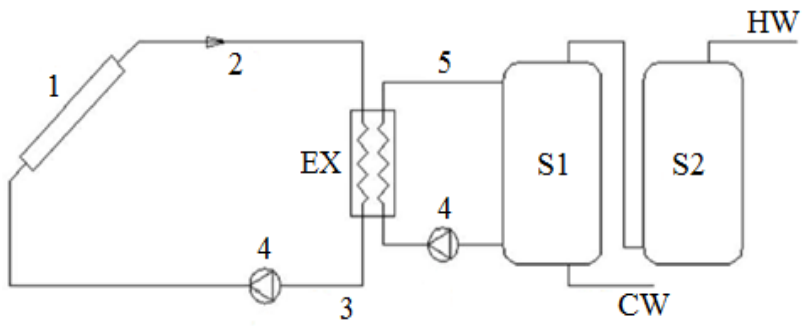

Figure 1. Schematic diagram of the solar system:

1 - collector's field; 2,3,5 - pipe network; 4 - pump; EX - heat exchanger; S1,S2 - storage tanks; HW - hot water, CW- cold water

hot water flows to the consumers. Behind the storage tank S2 an auxiliary heater is installed, which is included in the case when the solar system does not deliver the water heated to the required temperature $\left(60^{\circ} \mathrm{C}\right)$. System regulation is achieved by a differential thermostat, and it is based on the temperature difference between the fluid at the exit from the last collector in the series and the water in the tank.

\section{MATHEMATICAL MODEL}

Due to the daily and annual variability of the solar radiation and the temperature of the ambient air, as well as the changing demands of hot water and the operation of automation, the operation of the solar system is nonstationary. The thermal behavior of system's elements is described by differential equations of the mass and energy balance.

The instantaneous energy balance of the $i$ - th solar collector is described by differential equation, with time as independent variable, in the form:

$$
C_{c, i} \frac{d T_{m, i}}{d t}=A_{c, i} G \eta_{i}-\dot{m}_{f} c_{p, f}\left(T_{f, \text { out }}-T_{f, \text { in }}\right)_{i}
$$

The term on the left side of the equality sign in equation represents the amount of energy accumulated by the collector, while terms on the right side represent a usefully absorbed solar energy and the energy delivered to the fluid flowing through the collector. The analyzed solar system consists of parallel rows in a series connected five collectors and it was assumed that the fluid temperatures at the outlet from the previous one are equal to those at the inlet to the next in a series connected collector. The thermal efficiency of solar collector is defined by the ratio of useful energy delivered to the working fluid in the collector and the total energy of the solar radiation that falls at the surface of the collector in the observed time interval [8].
Official test data given by manufacturer contain three parameters $\left(\eta_{o}, a_{1}, a_{2}\right)$ which define the efficiency of the collector, which is given in the form:

$$
\eta=\eta_{o}-a_{1} \frac{T_{m}-T_{a}}{G}-a_{2} G\left(\frac{T_{m}-T_{a}}{G}\right)^{2}
$$

The heat losses of the collector are defined by the heat loss coefficients $\left(a_{1}\right.$ and $\left.a_{2}\right)$ and the temperature difference between the fluid in the collector and the ambient air. The optical efficiency is the maximum efficiency of the collector, when the collector's temperature is equal to that of environment and there are no heat losses to the environment.

The total radiation on the tilted surface was considered to include three components: beam, isotropic diffuse from the sky, and solar radiation diffusely reflected from the ground, i.e:

$$
G=G_{b} R_{b}+G_{d} \frac{1+\cos \beta}{2}+\left(G_{b}+G_{d}\right) \rho_{g} \frac{1-\cos \beta}{2}
$$

The beam radiation tilt factor $R_{b}$, the ratio of beam radiation on the tilted surface to that on a horizontal surface at any time, depends on the position of the sun in the celestial sphere, i.e, from the time of day and time of the year, the geographical latitude of the location s well as the orientation and inclination of the solar col-lector itself $[11,12]$. All of these parameters are included in the developed model of the displayed solar system.

The equation of the energy balance of the $i$ - th element or segment of the solar system (section of the distribution and return pipelines, storage tank) can be written in general form:

$$
\begin{aligned}
& C_{i} \frac{d T_{m, i}}{d t}=\sum_{j=1}^{k}\left(\dot{m}_{f} c_{p, f} T_{f}\right)_{j, \text { in }}- \\
& -\sum_{l=1}^{n}\left(\dot{m}_{f} c_{p, f} T_{f}\right)_{j, \text { out }}-U_{i}\left(T_{m, i}-T_{a, i}\right)
\end{aligned}
$$

where $U_{i}$ is the overall heat loss coefficient from the given element. The signs $k$ and $n$ refer to the number of inputs or outputs of the fluid into the given element /segment. Similar to the equation for collectors, a term on the left side of the equality sign in the previous equation represents the amount of energy accumulated by the given element. Terms on the right side represent energy flows due to fluid flow at the inlet and outlet from the given element, while the last member represents heat losses to the surrounding air. It is assumed that the water in the storage tank is fully mixed and the temperature stratification phenomenon does not occur.

In a heat exchanger the solar fluid transfers heat to the water in the accumulation circuit. By introducing the efficiency of the heat exchanger, the heat flow rate from one to the other fluid in heat exchanger can be written in dependence on the inlet temperatures of the fluids, i.e:

$$
\dot{Q}_{e x}=\varepsilon\left(\dot{m} c_{p}\right)_{\min }\left(T_{s, i n}-T_{a c, i n}\right)
$$

where $\left(\dot{m} c_{p}\right)_{\min }$ is a smaller of the fluid flow capacity in solar or accumulation circuit. The efficiency of the 
heat exchanger was calculated by using the $\varepsilon-N T U$ method [13], for the known construction of the exchanger (cross-flow single-pass) and the fluid flow regime in it.

The heat transfer rate delivered by solar system to water is given by equation:

$$
\dot{Q}_{s}=\dot{m}_{h w} c_{p}\left(T_{s 2}-T_{c w}\right)
$$

and the total heat transfer rate required to cover the load is given by:

$$
\dot{Q}_{l}=\dot{m}_{h w} c_{p}\left(T_{l}-T_{c w}\right)
$$

where $T_{l}$ - is required temperature of the hot water.

The solar fraction expresses the contribution of solar energy to the total heat load and predicts the long-term system performance. It represents the fractional reduction in the amount of energy that must be purchased [12]. For the $i$ - th month the solar fraction was calculated as [9]:

$$
f_{i}=\frac{Q_{s, i}}{Q_{l, i}}=\frac{\int_{\Delta t} \dot{Q}_{S} d t}{\int_{\Delta t} \dot{Q}_{l} d t}
$$

where is: $Q_{s, i}$ - solar energy delivered to the user during the month, $Q_{l, i}$ - energy required to cover the load for given month and $\Delta t$ - period of integration (one month).

\section{INPUT DATA AND SIMULATION PROCEDURE}

The solar radiation, ambient temperature, cold water temperature, hot water consumption, temperature of the air around pipe network and storage tanks must be known at each time step. The solar radiation and the ambient temperature were determined for the typical meteorological year for given location [14]. Temperature of the cold water supplied by public water is determined by the model given in the literature [15] but for the relevant input data for the given location of the system. Figure 2 shows the profile of the hot water consumption in percent for every hour during the day. This is the profile typical for hotels [7]. The total consumption of hot water is 5785 [1/day]. The analysis of system operation was conducted for the flat solar collectors of a known manufacturer for which the input data are known $\left(A_{c}=2,35 \mathrm{~m}^{2}, C_{c}=19 \mathrm{~kJ} / \mathrm{K}, \eta_{o}=0,791\right.$, $\left.\left.a_{1}=2,41 \mathrm{~W} /\left(\mathrm{m}^{2} \mathrm{~K}\right)\right), a_{2}=0,023 \mathrm{~W} /\left(\mathrm{m}^{2} \mathrm{~K}^{2}\right)\right)$. The heat loss coefficients for pipelines and storage tanks were calculated by the usual procedure with respect to the type of fluid, the fluid flow regime, the thermal isolation, and the environmental conditions in which the pipelines and storage tanks are located.

A system of ordinary differential equations which describe the dynamic behavior of the solar system was solved numerically by the fourth-order Runge-Kutta method. The program uses the condition that circulation pumps to be switched on when the difference between the temperature of solar fluid at the outlet from the last collector in the row and the water in the storage tank exceeds the set difference. When the pumps are turned off, there is no fluid flow through the system and in the equations of mass and energy balance terms containing mass flow are losing.

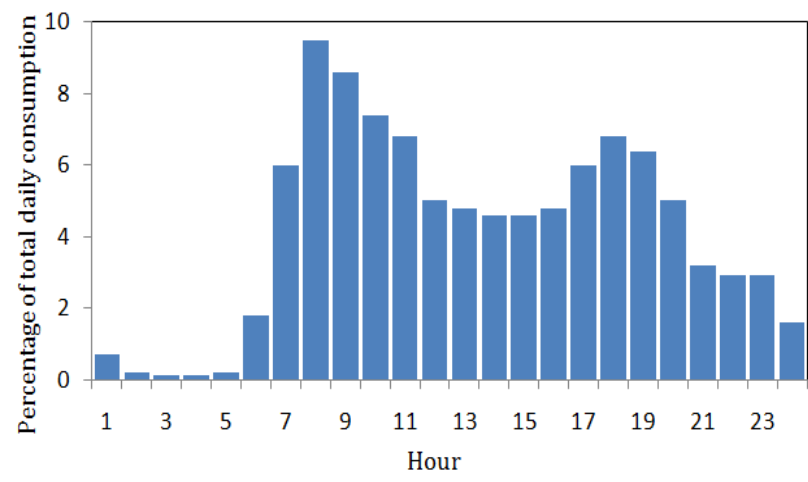

Figure 2. Daily profile of hot water consumption

\section{RESULTS AND ANALYSIS}

The shown results refer to the 15 th day of the corresponding month of the typical meteorological year. Figure 3 shows the values of the solar radiation incident on the collector surface, the temperature of the outdoor air and the temperatures of the water in storage tanks S1 and $\mathrm{S} 2$ in hours during the day for one spring and one summer month (April and July).

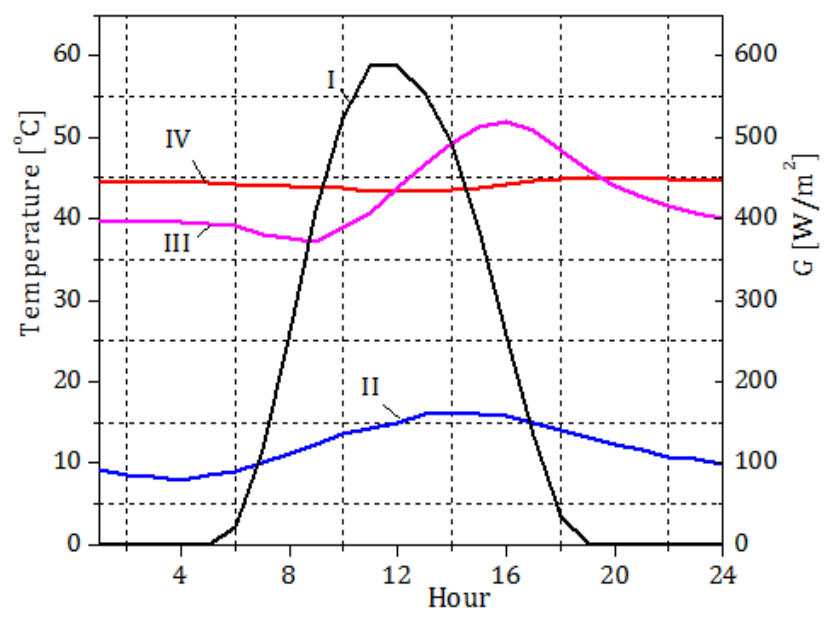

a) April

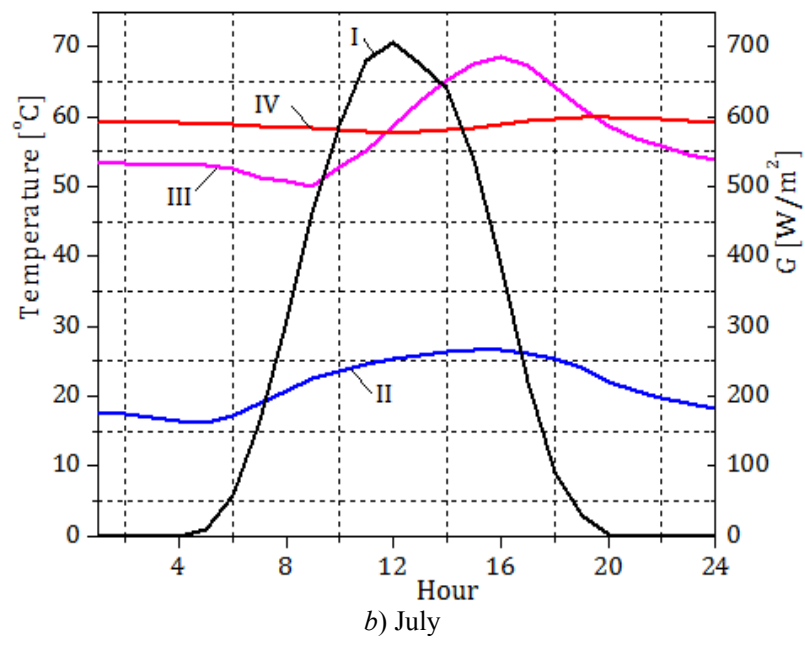

Figure 3. Daily profile of solar system parameters

I - solar incident radiation; II - ambient air temperature; III - water temperature in storage tank S1; IV - water temperature in storage tank S2 
As can be seen, the water temperature in the storage tank S2 does not change significantly during the day because the cold water does not enter the tank directly but only the hot water from the storage tank S1. A significant change in water temperature occurs in the storage tank $\mathrm{S} 1$, which is caused by the inflow of cold water, i.e. by consumption of hot water, as well as the inflow of energy from solar collectors. In April, the temperature $T_{S 2}$ is close to $45^{\circ} \mathrm{C}$, while the temperature $T_{S I}$ changes between $37^{\circ} \mathrm{C}$ and $52^{\circ} \mathrm{C}$. The nature of changes in these temperatures in July is the same, but due to the higher incedent solar radiation the temperatures are higher. The temperature $T_{S 2}$ is almost $60^{\circ} \mathrm{C}$, while the temperature $T_{S 1}$ changes between $50^{\circ} \mathrm{C}$ and $68^{\circ} \mathrm{C}$.

Figure 4 shows the daily profile of the water temperature in the storage tank S2 for different months (from April to October). Due to the assumption of unchanged water consumption during the year, the character of the changes in the temperature for the different months are similar, with the values changing the most in dependence on the available solar radiation.

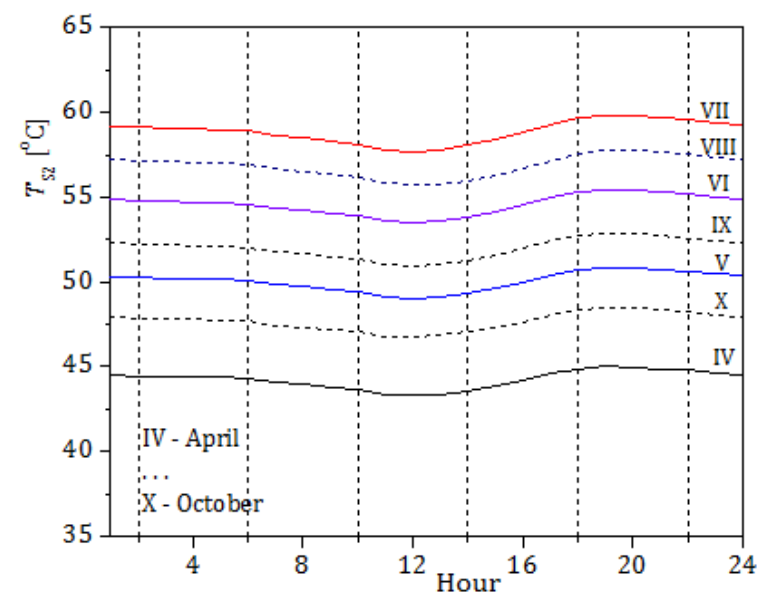

Figure 4. Water temperature in the storage tank S2

The daily profile of the useful energy supplied to the water is similar to the hot water consumption profile because the water temperature in storage tank S2 does not change significantly during the day, so the decisive influence has a consumption of the hot water. Figure 5 shows the monthly values of the useful solar energy supplied to the water.

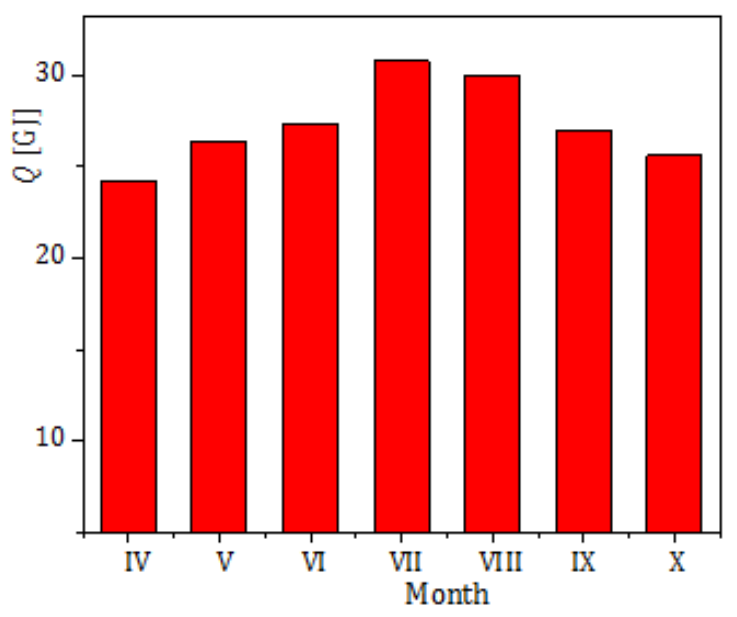

Figure 5. Monthly value of useful solar energy
The changes of hourly-averaged temperatures in a row of five in series connected collectors are shown in the Figure 6. The temperature changes are logical, caused by the values of the solar energy received and by the position of the collector in a series. The results obtained

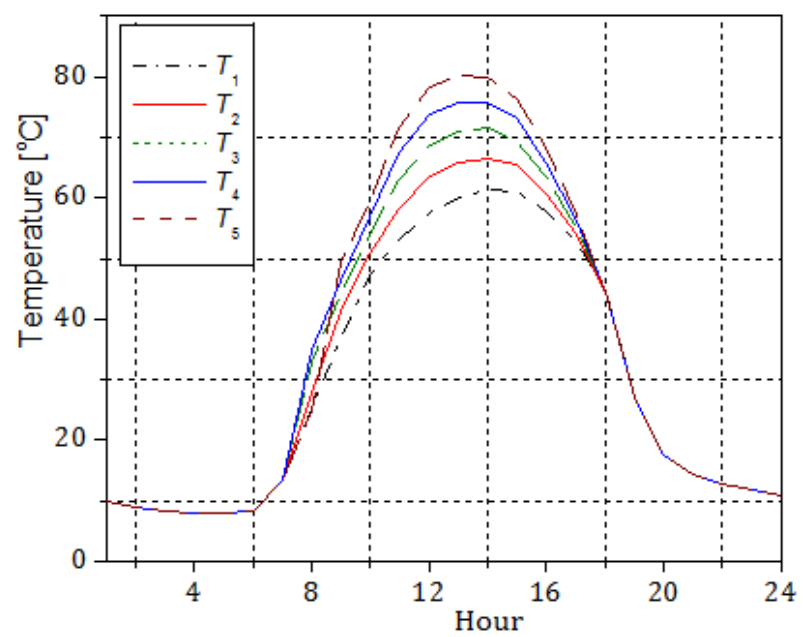

a) April

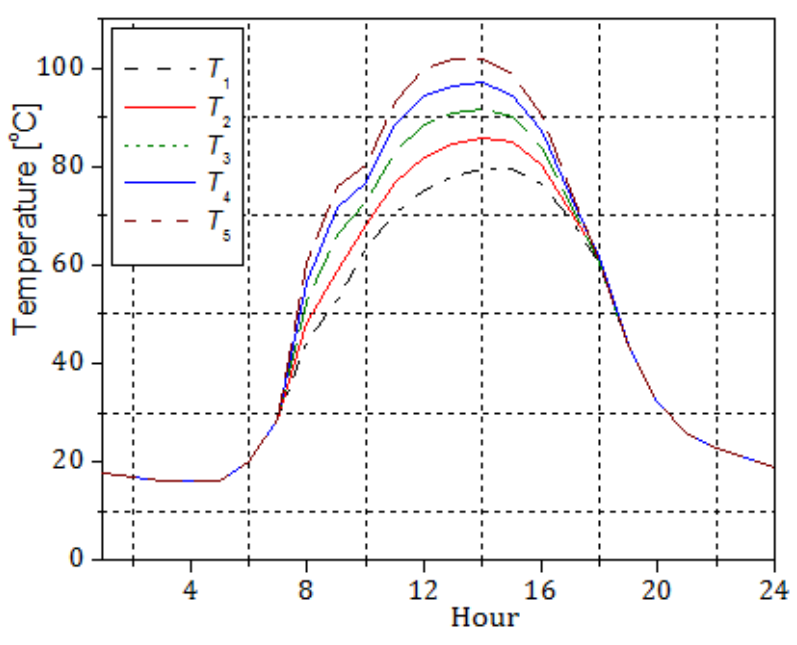

b) July

Figure 6. Hourly-averaged temperatures in series connected collectors (from 1 to 5)

by the simulation according to the model shown in this paper are compared with the results obtained by using the known $f$-chart method.

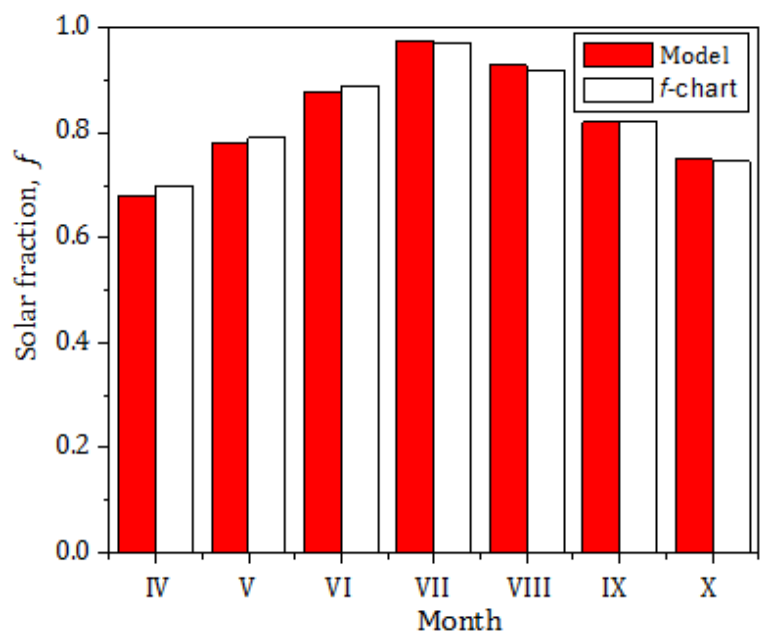

Figure 7. Solar fraction 
The $f$-chart method gives the solar fraction on the monthly load supplied by solar energy as a function of two dimensionless parameters. One parameter is related to the ratio of collector losses to heating loads, and the other is related to the ratio of absorbed solar radiation to heating loads [7,8,9]. Figure 7 shows comparison between solar fraction values obtained by computer simulation using the developed model and by using $f$-chart method. As can be seen, matching the values is very good.

\section{CONCLUSIONS}

A dynamic simulation model for thermal solar system was developed. The purpose of this model is to gain insight energy performances of components and of the whole solar system for water heating. The results obtained by computer simulations using the presented model are logical and easy to explain and they are well matching to the results obtained by using the $f$-chart method. The model provides an opportunity to analyze the influence of different climatic data (different system location), the dynamics of hot water consumption, the characteristics of system components, fluid flow, the orientation and inclination of the solar collectors and so on. It can be a good tool for optimization of the operation of solar systems for water heating.

\section{ACKNOWLEDGMENT}

This work was supported by Ministry of Education and Science of Republic of Serbia (Project TR33048).

\section{REFERENCES}

[1] Bakic, V., Pezo, M., Stojkovic, S.: Technical and Economic Analysis of Grid-Connected PV/Wind Energy Stations in the Republic of Serbia Under varying Climatic Conditions, FME Transactions 44, pp. 71-82, 2016.

[2] Kalogirou, S.: Solar thermal collectors and applications, Progress in Energy and Combustion Science 30, pp 231-295, 2004.

[3] Jamar, A., Majid, Z. A., Azmi, W. H., Norhafana, M., Razak, A. A.: A review of water heating system for solar energy applications, International Communications in Heat and Mass Transfer 76, pp. 178$187,2016$.

[4] Lisaboa, P., Fonseca-Costa, M. A.: Simulating the performance of solar water heating systems, Journal of Energy and Power Engineering 8, pp. 636-645, 2014.

[5] Lisaboa, P., Fonseca-Costa, M. A.: A software for simulation of solar water heating systems, Advanced in Fluid Mechanics and Heat \& mass Transfer, pp. 251-257, ISBN: 978-1-61804-114-2.

[6] Menger, O., Albin Z.: Analysis of thermal solar system parameters through dynamic simulation, Climate change- Energy awareness-Energy efficiency, Visegrad, 2005.

[7] Lin Qin: Analysis, modeling and optimum design of solar domestic hot water systems, Technical University od Denmark IBE, Report R-22, 1998.
[8] Nogueira, C. E. C et al.: Software for designig solar water systems, Renewable and Sustainable Energy Reviews 58, pp. 361-375, 2016.

[9] Dongellini, M., Falcioni, S., Morini, L.: Dynamic simulation of solar thermal sollectors for domestic hot water production, $70^{\text {th }}$ Conference of the Italian Thermal Machines Engineering Association, Vol 82, pp. 630-636, 2015.

[10]Beckman, W., Klein, S., Duffie, J.: Solar heating design by the f-chart method, Wiley Interscience Publication, New York, 1976.

[11]Duffie, J., Beckman, W.: Solar Engineering of Thermal Processes, Wiley Interscience Publication, New York, 2006.

[12] Kalogirou, S.: Solar engineering - processes and systems, Elsevier, 2009.

[13] Cengel. Y.: Heat Transfer - A Practical Approach, Second Edition, McGraw-Hill in Mechanical Engineering, London, 2002.

[14] Gojak, M., at al: Software for filtering, processing and visualization of meteorological data, solar.mas.bg.ac.rs , Belgrade 2012.

[15] RETScreen International, Clean Energy Project Analysis: RETScreen Engineering \& Cases Textbook, Solar Water Heating Project Analysis, Minister of Natural Resources Canada, 2001-2004.

\section{NOMENCLATURE}

$\begin{array}{ll}A & \text { area }\left[\mathrm{m}^{2}\right] \\ a_{1} & \text { heat loss coefficient }\left[\mathrm{W} /\left(\mathrm{m}^{2} \mathrm{~K}\right)\right] \\ a_{2} & \text { heat loss coefficient }\left[\mathrm{W} /\left(\mathrm{m}^{2} \mathrm{~K}^{2}\right)\right] \\ C & \text { heat capacity }[\mathrm{J} / \mathrm{K}] \\ c_{p} & \text { specific heat capacity at constant pressure } \\ f & \text { solar fraction, solar contribution } \\ G & \text { total incident solar radiation on the collector } \\ G_{b} & \left.\text { surface [W/m }{ }^{2}\right] \\ G_{d} & \text { beam radiation on horizontal surface }\left[\mathrm{W} / \mathrm{m}^{2}\right] \\ \dot{m} & \text { mass flow rate }[\mathrm{kg} / \mathrm{s}] \\ Q & \text { amount of heat }[\mathrm{J}] \\ \dot{Q} & \text { heat transfer rate }[\mathrm{W}] \\ T & \text { temperature }\left[\mathrm{K},{ }^{\circ} \mathrm{C}\right] \\ t & \text { time }[\mathrm{s}] \\ U & \text { overall heat loss coefficient }[\mathrm{W} / \mathrm{K}]\end{array}$

\section{Greek symbols}

$\beta \quad$ slope of the plane $\left[{ }^{\circ}\right]$

$\varepsilon \quad$ efficiency of the heat exchanger

$\eta \quad$ thermal efficiency of the collector

$\eta_{o} \quad$ optical efficiency of the collector

$\rho$ reflectance

\section{Superscripts}

a ambient air 


$\begin{array}{ll}a c & \text { accumulation } \\ c & \text { solar collector } \\ c w & \text { cold water } \\ e x & \text { exchanger } \\ f & \text { Fluid } \\ g & \text { ground } \\ h w & \text { hot water } \\ i & \text { i-th element, i-th month } \\ \text { in } & \text { inlet } \\ l & \text { load } \\ m & \text { average } \\ \text { out } & \text { outlet } \\ s & \text { solar } \\ \text { s2 } & \text { storage tank S2 }\end{array}$

СИМУЛАЦИЈА РАДА СОЛАРНОГ СИСТЕМА ЗА ЗАГРЕВАЊЕ ВОДЕ

\section{М. Гојак, Ф. Љубинац, М. Бањац}

У раду је приказан математички модел рада соларног система за загревање воде. Анализирани соларни систем садржи равне соларне колекторе, два акумулациона резервоара за воду, спољашњи размењивач топлоте и допунски извор енергије. Примењени модел омогућава симулацију рада и одређивање одговарајућих енергетских показатеља рада система и његових елемената за различите локације (климатске услове), оријентацију колектора, термичких карактеристика компонената система, као и различиту динамику коришћења топле воде. Резултати симулације су приказани за дане типичне метеоролошке године за Београд и дневни профил коришћења топле воде. Приказана је анализа енергетских карактеристика система. Резултати добијени нумеричком симулацијом су поређени са резултатима добијеним применом $f$-chart методе прорачуна. 